\title{
Penerapan Teknologi Pengolahan Dan Peningkatan Distribusi Air Bersih Di Lingkungan Masyarakat Rt 36 Kelurahan Graha Indah
}

\author{
Gozali Gozali, Bambang Jati Kusuma, Subur Mulyanto \\ Jurusan Perhotelan Politeknik Negeri Balikpapan \\ Penulis Koresponden gozali@poltekba.ac.id
}

\begin{abstract}
ABSTRAK
Kontur tanah Kota Balikpapan adalah berbukit-bukit menyebabkan tidak semua warga mendapatkan pasokan air bersih dari PDAM sehingga banyak warga yang mengandalkan air tanah atau sumur bor untuk digunakan kegiatan sehari-hari. Air tanah di Kota Balikpapan sebagian besar masih dibawah standar air bersih terutama di masyarakat sekitar lingkungan Kelurahan Graha Indah yakni air tanahnya berbau logam dan berwarna kuning. Hal ini terjadi dikarenakan air tanah yang dikelola oleh masyrakat tidak diolah terlebih dahulu ataupun diolah terlebih dahulu karena keterbatasan pengetahuan maka air tanah yang dihasilkan tetap berwarna kuning. Meskipun air tanah yang digunakan untuk kegiatan sehari-hari masih dibawah standar air bersih masyarakat dan santri masih tetap memanfaatkan air tanah tersebut untuk mandi, mencuci piring, mencuci pakaian dan kegiatan yang lain. Dengan keadaan tersebut maka metode yang digunakan menyelesaikan masalah tersebut menggunakan Teknologi Pengolahan Air bersih yang terdiri dari proses netralisasi, aerasi, koagulasi, flokulasi, sedimentasi dan filtrasi. Tujuan dari Pengabdian kepada Masyarakat ini adalah: 1 . Memberikan pelatihan dan keterampilan kepada para masyarakat, untuk mengetahui cara mengolah air yang berbau besi dan berwarna kuning menjadi air bersih. 2. Mengaplikasikan pemahaman yang sudah diberikan pada saat pelatihan menjadi suatu teknologi tepat guna beserta memberi pengetahuan tentang cara pemeliharaan teknologi tepat guna tersebut.
\end{abstract}

Kata Kunci: teknologi air, distribusi air, pengolahan air

\section{PENDAHULUAN}

Masyarakat disekitar Kelurahan Graha Indah Balikpapan terdiri dari 200 Kepala Keluarga dengan jarak $1.5 \mathrm{~km}$ dari Politeknik Negeri Balikpapan. Masyarakat tersebut masih mengandalkan air tanah yang masih bau logam dan berwarna kuning. Tentu saja dengan kondisi tersebut akan berakibat buruk bagi kesehatan masyarakat pada jangka panjang seperti masalah pada kulit dan gatal-gatal. Kondisi lingkungan Rt 36 Kelurahan Graha Indah Balikpapan dapat dilihat pada Gambar 1.

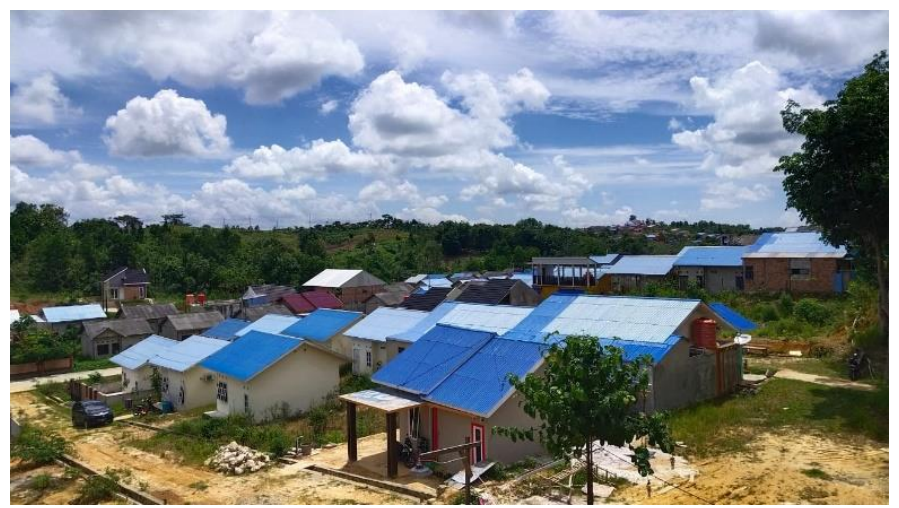

Gambar 1. Kondisi Lingkungan Rt 36 Kelurahan Graha Indah 
Menurut Danielyn (2009) hal ini dikarenakan kondisi air tanah di Balikpapan sebagian besar mengandung logam dengan konsentrasi yang tinggi sehingga mempengaruhi kondisi air tanah menjadi bau dan berwarna yang memberikan arti bahwa air tanah tersebut mengandung $\mathrm{Fe}$ yang melebihi kadar maksimal dalam kualitas perairan golongan B yaitu lebih dari $1 \mathrm{mg} / \mathrm{l}$ (Permenkes RI No 416/Per/IX/1990).

Sebenarnya di Lingkungan Rt 36 sudah pernah mencoba untuk mengatasi krisis air bersih yaitu dengan cara hanya proses pengendapan selama 2 hari. Karena kebutuhan air yang cukup banyak dan keterbatasan pengetahuan tentang pengolahan air bersih maka proses pengolahan airnya membutuhkan waktu yang lama sehingga distribusi air ke rumah warga tidak optimal dan air yang dihasilkan tetap masih berwarna kuning dan berbau logam. Pengolahan air bersih menurut lingkungan Rt 36 Kelurahan Graha Indah dapat dilihat pada Gambar 1.2.

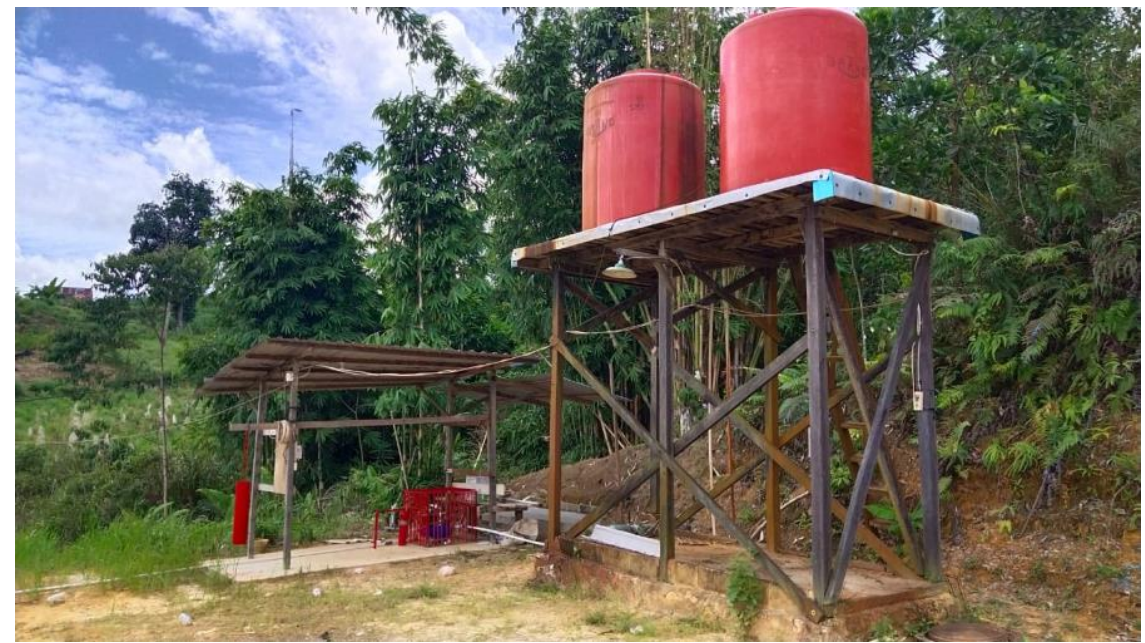

Gambar 2. Proses Penampungan dan Filtrasi yang pernah di coba di Rt 36 Graha Indah

Jika dilihat paga Gambar 2 ternyata proses pengolahan air bersih yang sudah dicoba masih menggunakan proses filtrasi dan hasilnya masih belum optimal dimana air tanah yang akan diolah adalah air yang mengandung logam fe yang tinggi sehingga mengakibatkan bak filter (yang awalnya putih sudah berwarna coklat) dan bak penampung yang berwarna biru sebagian berubah warnanya menjadi warna coklat (warna logam besi yang berkarat). Padahal jika air tanah yang akan diolah mengandung logam Fe yang tinggi dengan ditandai kondisi fisik air yang berbau dan berwarna maka secara konsep pengolahan air bersih dapat menggunakan proses netralisasi, aerasi, koagulasi, flokulasi, sedimentasi dan filtrasi. Kondisi dan situasi sekarang masyarakat masih tetap menggunakan air tanah yang bau dan berwana kuning ini untuk mandi, mencuci piring, mencuci pakaian, dan kebutuhan sehari-hari lainnya yang nantinya akan berakibat buruk bagi kesehatan masyarakat, pada jangka panjang.

Kondisi kontur tanah di Kelurahan Graha Indah yang berbukit-berbukit menyebabkan tidak semua warga mendapatkan pasokan air bersih dari PDAM sehingga banyak warga yang mengandalkan air tanah sebagai pasokan air bersih.

Air tanah adalah semua air yang terdapat di bawah permukaan tanah termasuk air yang terdapat dalam pori-pori tanah. Kedalaman air tanah tidak sama pada setiap tempat tergantung pada ketebalan lapisan permukaan di atasnya dan kedudukan lapisan air tanah tersebut. Permukaan yang merupakan bagian atas dari tubuh air disebut permukaan preatik. Volume air yang meresap ke dalam tanah tergantung pada jenis lapisan batuannya. Terdapat dua jenis 
lapisan dalam tanah yaitu lapisan kedap air (impermeable) dan lapisan tak kedap air (permeable).

Sedangkan jenis tanah yang terdapat di Kota Balikpapan adalah sebagai berikut :

1. Alluvial, terdiri dari material pasir, lempung dan lumpur yang terbentuk dalam lingkungan sungai dan pantai. Jenis tanah ini menempati kira-kira seluas 5\% dari wilayah Kota Balikpapan. Pada jenis tanah Alluvial ini tersedia minimal cukup unsur hara yang berguna bagi tumbuh-tumbuhan namun sebagian besar tanah ini dipengaruhi oleh unsur bahan induk sehingga menjadikan kurang subur bagi lahan pertanian.

2. Podsolik Merah Kuning, jenis tanah ini menempati wilayah Kota Balikpapan sekitar $80 \%$, keadaan tekstur tanah liat, porositas jelek dan mudah larut bersama air.

3. Tanah Pasir, sekitar $15 \%$ dari wilayah Kota Balikpapan, tanah pasir ini mengandung kuarsa, lempung serta serpih dengan sisipan napal dan batu bara, berwarna kecoklatan agak kelabu, porositas baik, rapuh dan tingkat erosi sangat tinggi.

Kondisi jenis tanah ini salah satu yang penyebab mengapa air tanah di Balikpapan kurang memenuhi standar kualitas air bersih. Persyaratan bagi masing-masing standar kualitas air masih perlu ditentukan oleh 4 (empat) aspek yaitu : persyaratan fisis, kimia, biologis, radiologis. Persyaratan fisis ditentukan oleh faktor-faktor kekeruhan, warna, bau maupun rasa. Persyaratan kimia ditentukan oleh konsentrasi bahan-bahan kimia seperti arsen, klor, tembaga, sianida, besi dan sebagainya. Persyaratan biologis ditentukan baik oleh mikroorganisme yang pathogen, maupun yang non pathogen. Kualitas air tanah masih di bawah standar air bersih karena kandungan logam besi (Fe) sangat tinggi yaitu $1,0 \mathrm{mg} / \mathrm{l}$ (PerMenKes RI No 416/Per/IX/1990). Kondisi air tanah dan kandungan kimianya berturut-turut ditunjukkan pada gambar 3.

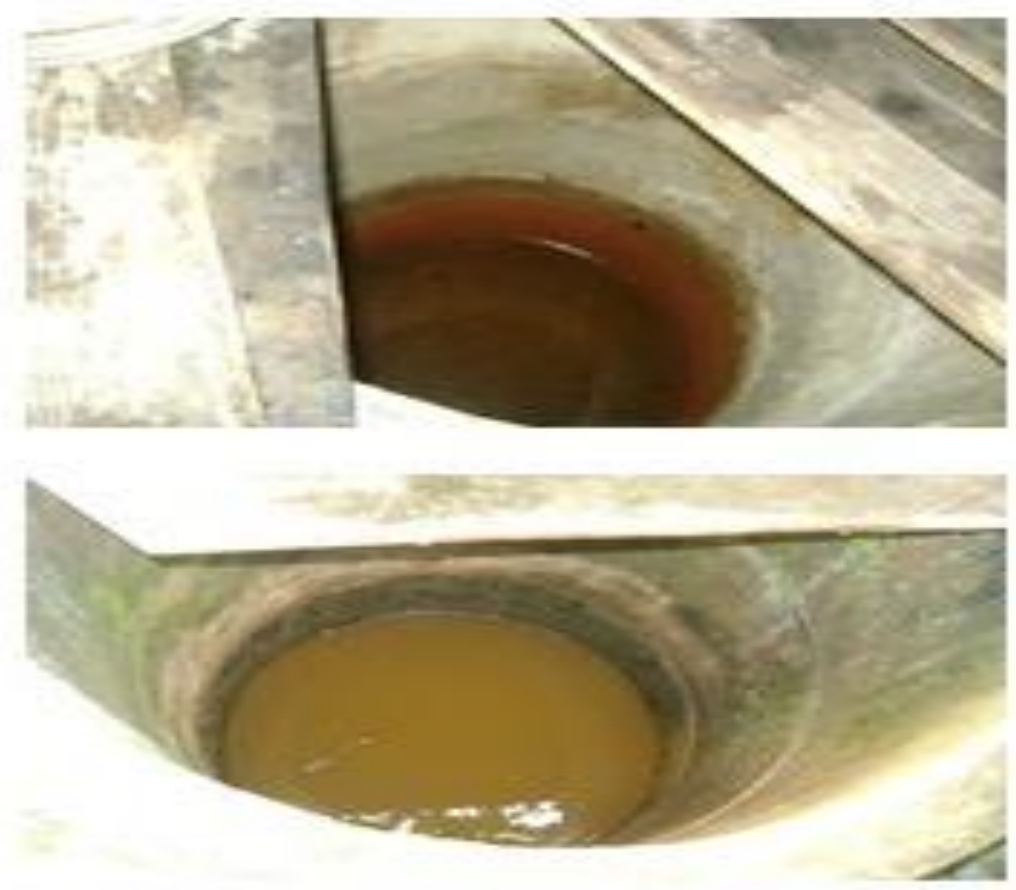

Gambar 3. Kondisi air tanah atau air sumur dimasyarakat 
Tabel 1. Kandungan Air Tanah di Balikpapan

\begin{tabular}{|c|c|c|c|c|}
\hline No & Parameter & Satuan & $\underset{\text { si }}{\text { Komposi }}$ & $\begin{array}{c}\text { Kadar } \\
\text { maksimum yang } \\
\text { diperbolehkan }\end{array}$ \\
\hline & \multicolumn{4}{|l|}{ FISIKA } \\
\hline 1 & $\mathrm{Bau}$ & & - & - \\
\hline 2 & $\begin{array}{l}\text { Jumlah Zat Padat Terlarut } \\
\text { (TDS) }\end{array}$ & $\mathrm{mg} / \mathrm{l}$ & 3000 & 1500 \\
\hline 3 & Kekeruhan & NTU & 48 & 25 \\
\hline 4 & Rasa & & - & - \\
\hline 5 & Suhu & ${ }^{0} \mathrm{C}$ & 30 & $\begin{array}{l}\text { Suhu udara k/l } \\
\qquad 30^{\circ} \mathrm{C}\end{array}$ \\
\hline 6 & Warna & TCU & 65 & 50 \\
\hline \multirow[t]{2}{*}{7} & $\mathrm{pH}$ & $\mathrm{mg} / \mathrm{l}$ & 7,6 & $6,9-9,0$ \\
\hline & Kimia & & & \\
\hline 1 & Besi (Fe) & $\mathrm{mg} / \mathrm{l}$ & 7,53 & 1,0 \\
\hline 2 & Flourida & $\mathrm{mg} / \mathrm{l}$ & 0,18 & 1,5 \\
\hline 3 & Kesadahan & $\mathrm{mg} / \mathrm{l}$ & 302 & 500 \\
\hline 4 & Klorida & $\mathrm{mg} / \mathrm{l}$ & 95 & 600 \\
\hline 5 & Mangan (Mn) & $\mathrm{mg} / \mathrm{l}$ & 0,49 & 0,5 \\
\hline 6 & Nitrat & $\mathrm{mg} / \mathrm{l}$ & 0,49 & 10 \\
\hline 7 & Nitrit & $\mathrm{mg} / \mathrm{l}$ & 5,3 & 1,0 \\
\hline 8 & Seng & $\mathrm{mg} / \mathrm{l}$ & 0,2 & 15 \\
\hline 9 & Sulfat & $\mathrm{mg} / \mathrm{l}$ & 89 & 400 \\
\hline 10 & Zat Organik & $\mathrm{mg} / \mathrm{l}$ & 34 & 10 \\
\hline
\end{tabular}

Sedangkan kondisi air tanah yang gunakan oleh Masyarakat Rt 36 Kelurahan Garaha Indah dapat dilihat pada gambar 4.

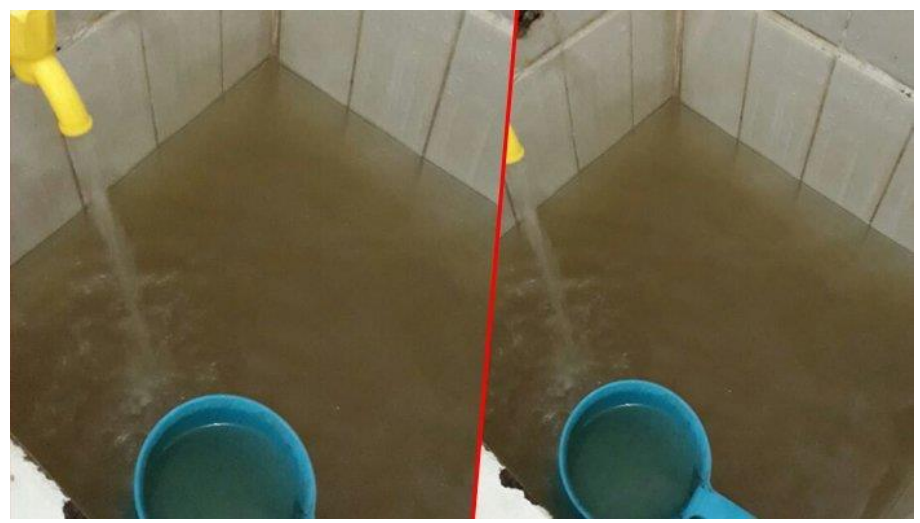

Gambar 4. Kondisi air di Lingkungan Rt 36 Graha Indah Balikpapan Utara

Berdasarkan informasi dari masyarakat disana dari pertama mereka menempati rumah sampai sekarang masyarakat belum pernah merasakan air bersih, banyak masyarakat dan santri yang terpaksa memanfaatkan air yang dibawah standar air bersih. Tentu saja hal ini akan berakibat kurang baik bagi kesehatan masyarakat dan santri pada jangka pendek, kualitas yang kurang baik dapat mengakibatkan muntaber, diare, kolera, tipus, atau disentri. Hal ini dapat terjadi pada keadaan sanitasi lingkungan dan kualitas air yang buruk. Bila air tanah dan air permukaan 
tercemari oleh kotoran, secara otomatis kuman kuman tersebar ke sumber air yang dipakai untuk keperluan rumah tangga. Dalam jangka panjang, air yang berkualitas rendah atau dibawah standar air bersih dapat mengakibatkan penyakit keropos tulang, korosi gigi, anemia, dan kerusakan ginjal. Hal ini terjadi karena terdapatnya logam logam yang berat yang banyak bersifat toksik (racun) dan pengendapan pada ginjal (Kusnaedi, 2002). Sehingga solusi yang ditawarkan ini yakni pembuatan alat penjernih air dengan transfer Ipteks berupa pelatihan cara penggunaan dari alat tersebut serta solusi yang harus diatasi jika alat tersebut mengalami masalah.

Sehingga dari permasalahan diatas maka perlu adanya inovasi Teknologi yang mendukung untuk meningkatkan kualitas air bersih yang berstandar kesehatan masyarakat yang memenuhi parameter kualitas air dari segi fisika, kimia dan biologi yaitu dengan membantu memberikan pelatihan dan ketrampilan tentang cara merawat, memelihara alat pengolahan tersebut dan membuat Teknologi Pengolahan air bersih yang terdiri dari proses netralisasi, aerasi, koagulasi, flokulasi, sedimentasi dan filtrasi yang diharapkan dapat menyisihkan kadar besi dan menjadikan air tanah yang berbau dan berwarna kuning tadi akan berubah menjadi air bersih yang sehat yang dapat digunakan untuk masyarakat dalam keperluan sehari-harinya.

\section{METODE PELAKSANAAN}

Dalam pengabdian kepada masyarakat ini melibatkan masyarakat. Metode pelaksanaan meliputi beberapa tahap:

1. Tahap pendahuluan sebelum pelatihan tim PKM menyiapkan alat dan bahan yang diperlukan seperti bak penjernihan, pipa 2 in, ball valve, elbow, gergaji, lem, reduser, shok drat, pompa air. Sedangkan bahannya antara lain kerikil, karbon aktif dan pasir silika.

2. Melakukan kesepakatan waktu dan tempat untuk dilakukan kegiatan pelatihan antara tim PKM dengan Mitra.

3. Pertemuan pertama didalam Pelatihan tim PKM memberikan pemahaman terhadap air tanah yang kualitasnya dibawah standar air bersih beserta efek yang terjadi jika dikonsumsi oleh manusia.

4. Kemudian Tim PKM memberikan penjelasan tentang air bersih beserta manfaatnya.

5. Selanjutnya Tim PKM memberikan pengetahuan tentang teknologi pengolahan air secara lisan dan praktek/demonstrasi untuk membuat dan merakit bak koagulasi dan flokulasi.

6. Kemudian Tim PKM bersama masyarakat, membuat alat teknologi tepat guna yang meliputi bak penjernihan, instalasi pipa, pompa secara bersama-sama.

\section{HASIL DAN PEMBAHASAN}

Dari semua rangkaian kegiatan yang dilakukan, warga keluarahn graha indah sangat antusias mengikuti kegiatan ini, hal ini terlihat dari banyaknya warga yang terlibat dalam setiap kegiatan yang dilaksanakan mulai dari sosialisasi kegiatan, dan pengerjaan struktur bak penjernihan. Kegiatan ini menghasilkan teknologi tepat guna berupa bak penampungan yang berfungsi sebagai media filtrasi air bersih. 


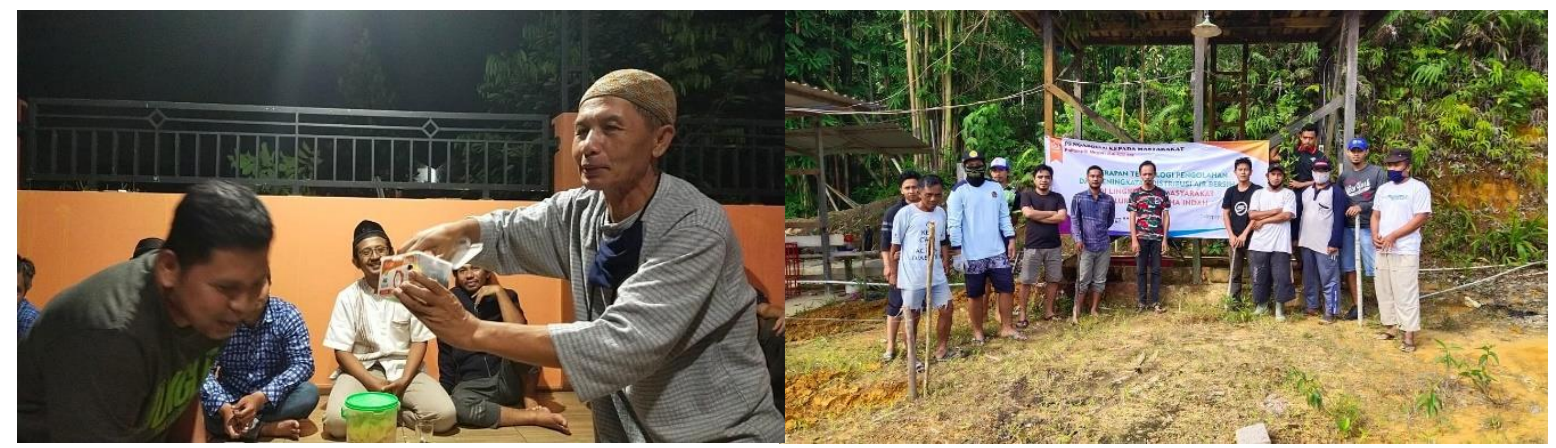

Gambar 5. Tim PKM melakukan sosialisasi kegiatan

Kegiatan yang pertama adalah Tim PKM melakukan sosialisasi kepada warga kelurahan graha indah terkait semua rangkaian kegiatan yang akan dilaksanakan, mulai dari penjelasan program, jadwal pelaksanaan dan model bak penjernihan yang akan dibuat.

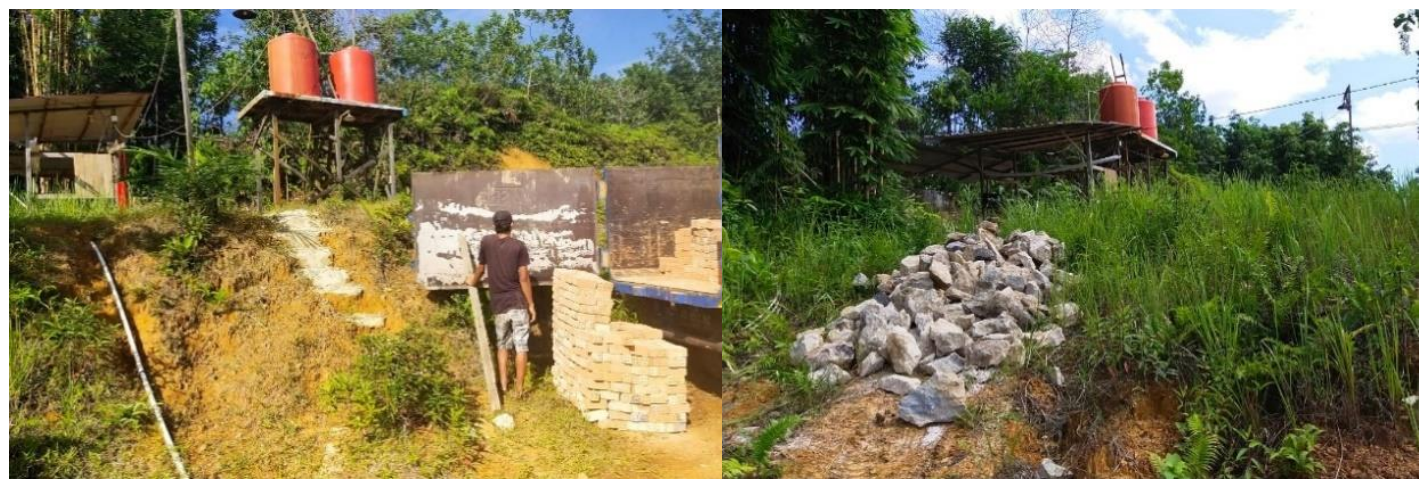

Gambar 6. Penyiapan bahan dan peralatan

Kegiatan yang kedua adalah Tim PKM menyiapkan bahan dan peralatan yang akan digunakan untuk membuat bak penjernihan.

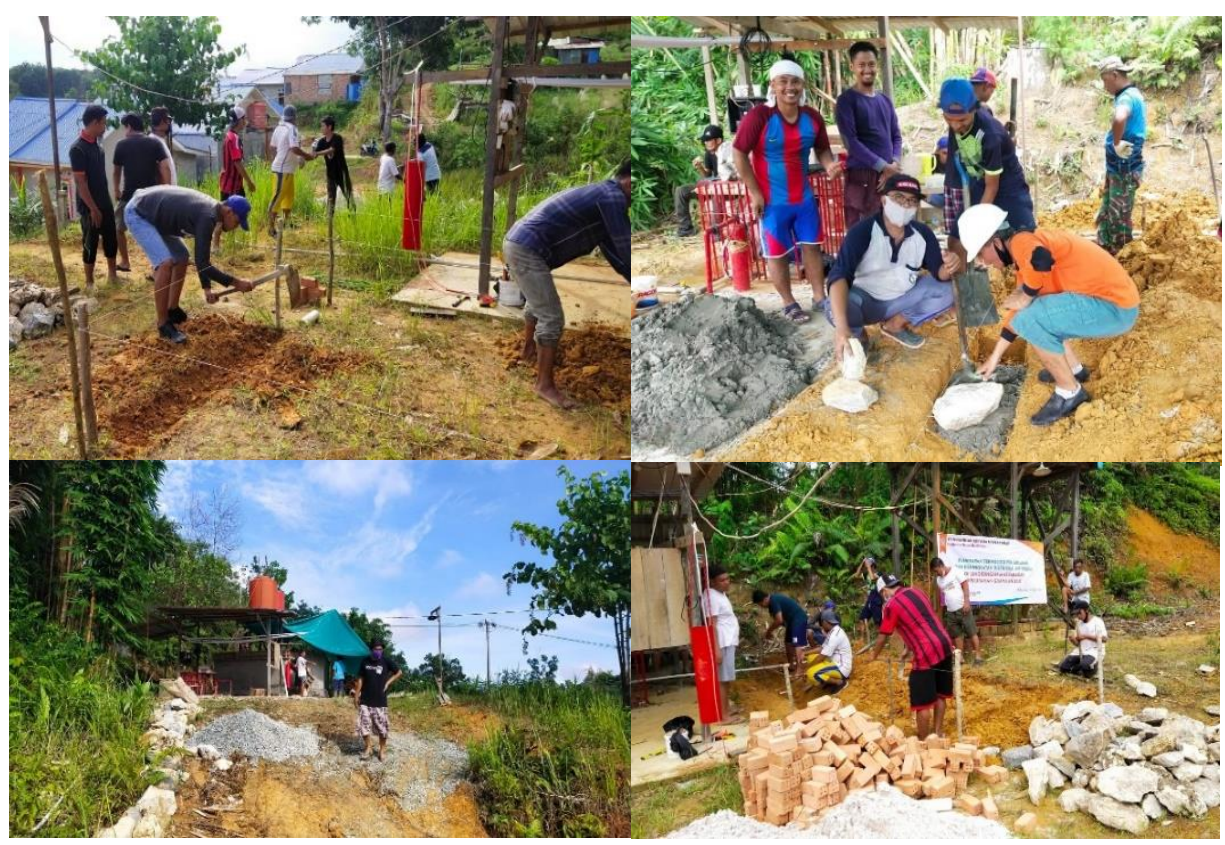

Gambar 7. Pengerjaan Struktur Bak Penjernihan 
Kegiatan ketiga adalah Tim PKM bersama warga kelurahan graha indah secara swadaya secara antusias melakukan pembangunan bak penjernihan dengan ukuran $4 \times 2 \mathrm{~m}^{2}$. Kegiatan ini dimulai dari pengukuran, penggalian pondasi, perakitan besi, dan pemasangan batu gunung. Selanjutnya dilakukan pegecoran sloof, pemasangan dinding bak penjernihan dan finishing struktur bak penjernihan.

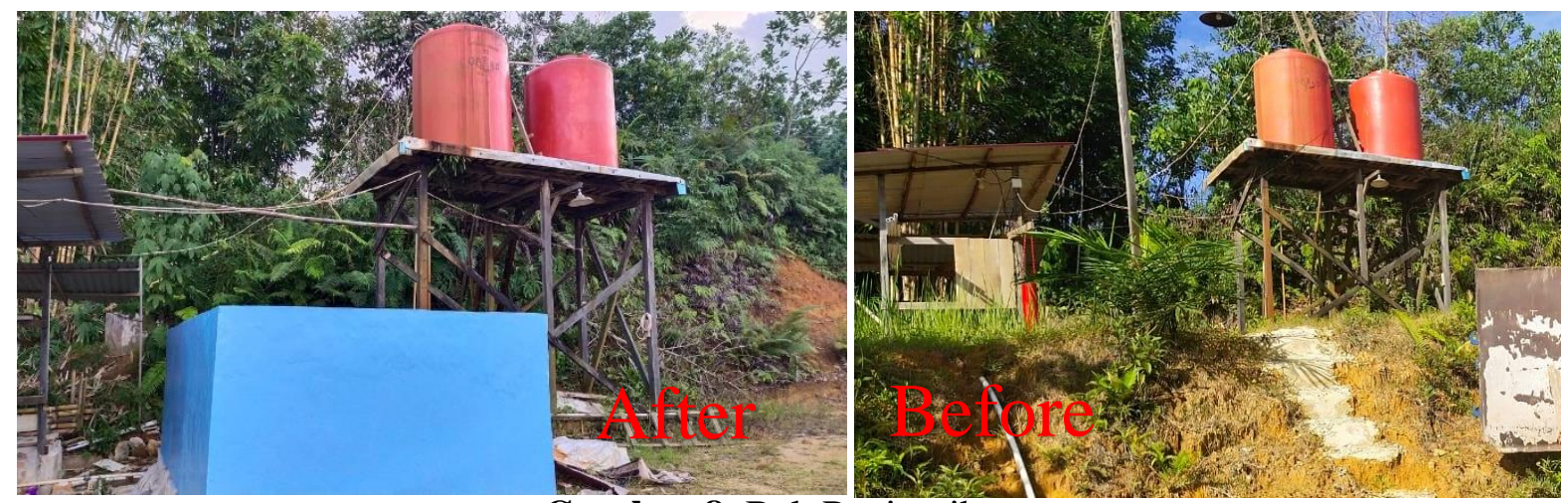

Gambar 8. Bak Penjernihan

Bak penjernihan yang dihasilkan melalui kegiatan ini dapat menampung kurang lebih 9000 liter air. Dengan demikian kebutuhan air bersih warga kelurahan graha indah dapat terpenuhi dengan baik.

\section{KESIMPULAN DAN SARAN}

Berdasarkan hasil yang dicapai dapat disimpulkan bahwa kegiatan program pengabdian kepada masyarakat yang berjudul "Penerapan Teknologi Pengolahan dan Peningkatan Distribusi Air Bersih Di Lingkungan Masyarakat Rt 36 Kelurahan Graha Indah Balikpapan Utara" dapat dilaksanakan dengan baik. Kegiatan ini menghasilkan produk berupa bak penjernihan air bersih dalam rangka meningkatkan kualitas mutu air bersih dan meningkatkan kuantitas distribusi air yang dapat bermanfaat bagi masyarakat. Dengan adanya bak penampungan yang dapat memuat kurang lebih $9000 \mathrm{~m}^{3}$ air bersih dapat mengatasi keterbatasan air bersih yang digunakan mitra untuk kebutuhan sehari-hari. Adapun rekomendasi yang dapat diberikan untuk kegiatan selanjutnya adalah mengembangkan teknologi yang ramah dan murah yang dapat meningkatkan kualitas mutu air.

\section{DAFTAR PUSTAKA}

Danielyn, 2009. Analisa kualitas air bersih di Balikpapan, Balikpapan,

Peraturan Menteri Kesehatan, 2017. Syarat-syarat dan pengawasan Kualitas Air, PerMenKes RI No 32/MENKES/2017, Jakarta.

Kusnaedi, 2002. Mengolah air gambut dan air kotor untuk air minum. Jakarta:Suradaya.

Said, N,I, 2003. Metode Praktis Penghilangan Zat Besi dan mangan di dalam Air Minum, Jakarta : Kealair BPPT, 2003. 